\title{
Existe anti-semitismo no Novo Testamento?
}

\author{
Pe. Jesus Hortal, S.J.
}

A primeira questão polêmica, insistentemente levantada pelos judeus em face do cristianismo, especialmente após a Segunda Guerra Mundial, é: existe anti-semitismo no Novo Testamento e mais especificamente em São Paulo? Sabemos que os nossos escritos sagrados são heterogêneos e redigidos ao longo de mais de setenta anos. O vocabulário e o estilo neles empregados variam notavelmente, de acordo com a época e os destinatários. Por isso, eles não podem ser interpretados sem levar em conta os leitores para os quais foram preparados.

Deixando, pois, inicialmente de lado os escritos paulinos, dos quais falaremos mais adiante, olhemos os Evangelhos. Mesmo admitindo, com a maior parte dos papirólogos atuais, a identificação de fragmentos da caverna 7 de Qumrã como pertencentes ao Evangelho de Marcos - o que indicaria certo relacionamento com os essênios -, é certo que esse Evangelho é plenamente "cristão" e que foi redigido após a separação definitiva entre Igreja e Sinagoga, operada com a perseguição herodiana do ano 40 da nossa era. É o momento em que Tiago o Maior foi preso e executado. Ao mesmo tempo, o grupo dos judeu-cristãos já tinha começado a regredir e a perder importância na comunidade jerosolimitana. Quase certamente, os outros três Evangelhos, pelo menos na versão que conservamos, são posteriores à catástrofe do ano 70, quando Jerusalém foi destruída e o povo de Israel disperso e quando os cristãos, seguindo o conselho de Jesus, fugiram "para as montanhas"

${ }^{1}$ Cf. Mt 24,16; Mc 13,14; Lc 21,21. 
evangelistas escreveram, pois, com a consciência de formarem uma comunidade à parte em face da sinagoga. Por isso, tentaram marcar as diferenças. Ao se difundir no seio do povo de Israel a nova religião, era necessário para ela acentuar a própria individualidade, contra a nostalgia do culto esplendoroso do templo e as formas de piedade tradicionais. É suficiente dar uma olhada na Carta aos Hebreus, para compreender essa concorrência acirrada e o modo como foi enfrentada pelos autores neo-testamentários. O ponto fundamental da separação era e continuará a ser o caráter único de Jesus, algo inaceitável para o judaísmo. Contra toda a tradição rabínica, que reconhece uma pluralidade de mestres, o cristianismo apresentava um só, atribuindo-lhe ainda natureza divina. Os cristãos, que no começo, eram majoritariamente de origem judia, passaram a ser depois fundamentalmente gentios convertidos, inclusive um bom número de prosélitos, influenciados previamente pelo judaísmo. Nesse contexto, os evangelistas tentaram mostrar as causas que levaram Jesus à morte. Mas, escrevendo para leitores predominantemente não hebreus, simplificaram as suas descrições, a fim de torná-las compreensíveis a todos e, talvez, de demonstrar que o conflito ideológico entre judaísmo e cristianismo era irreversível. Daí surgiram às denominações genéricas, que aparecem ao longo dos seus relatos: os adversários de Jesus são "os escribas e fariseus" (nos Sinóticos) ou "os judeus" (em João) ${ }^{2}$; raramente, os "herodianos"; muito menos, os romanos.

Apesar da acusação genérica contra os fariseus, que ficou proverbial no discurso cristão, devemos reconhecer que a linguagem e muitas das idéias pregadas por Jesus se enquadram dentro da tradição rabínica; ainda mais, dentro da escola dos fariseus. É verdade que os que, na expressão dos evangelistas, se tornaram inimigos de Jesus parecem formar um grupo compacto e numeroso, que poderia ter sido constituído fundamentalmente pelos próprios fariseus. Advirtamos, porém, que os mesmos escritores, dentro da narrativa dos fatos que conduziram à morte de Jesus, fazem alusão também aos "sumos sacerdotes", ao "sinédrio", aos "príncipes [principais] dos sacerdotes", sem esquecer os "herodianos" e até "a multidão" e "o povo". Essa multiplicidade de denominações mostra claramente que os relatos não foram redigidos com a exatidão histórica que teríamos desejado. Curiosamente, os romanos, que, pelo menos, foram os responsáveis legais da condenação e os

\footnotetext{
${ }^{2}$ Marcos, o mais primitivo dos evangelistas, usa seis vezes a expressão "os judeus"; Mateus e Lucas a empregam cinco vezes cada um. Mas destes três evangelistas, apenas Marcos a usa uma vez referindo-se aos que poderiam ser qualificados de "inimigos" do cristianismo. João, ao contrário, o faz nada menos do que sessenta e cinco vezes. Lembremos que João escreveu certamente após a destruição de Jerusalém, quando a fratura entre cristianismo e judaísmo era irreversível e os seus leitores eram, na sua grande maioria, oriundos do paganismo e, portanto, desconhecedores das diversas correntes judaicas de pensamento
} 
executores da pena capital contra Jesus, quase são esquecidos e desculpados. Até na tradição popular, o centurião que transpassou o costado de Jesus, transformou-se em "São Longinos" e não faltaram tentativas de atribuir também o caráter de santa à mulher de Pilatos, conhecida como Prócula. Dá a impressão de que o cristianismo nascente, ao mesmo tempo em que, tomando consciência de sua identidade, afirmava a própria personalidade em face do judaísmo, queria evitar, a todo custo, o conflito com o poder dominador, o Império Romano. Por outro lado, para leitores de tradição não judaica, seria impossível explicar todas as divisões das escolas rabínicas. Daí o recurso a uma denominação genérica, que não podia ter, na sua origem um sentido anti-semita, pois a quase totalidade dos autores do Novo Testamento foram judeus de raça, que não pretendiam renegar as suas origens. Pode ser iluminadora, a esse respeito, a distinção que é feita pelo documento Nós recordamos, do Pontifício Conselho para o Diálogo Religioso com o Judaísmo, entre "antijudaísmo" e "anti-semitismo"3. O antijudaísmo brota da rivalidade religiosa; o anti-semitismo, da étnica. Nos evangelistas, aparecem claros traços de antijudaísmo; nenhum de anti-semitismo.

Uma comparação do Novo Testamento com os textos de Qumrã - escritos por uma comunidade de judeus piedosos, provavelmente de essênios, em conflito com os dirigentes do Templo - mostra que o distanciamento e as condenações entre grupos rivais dentro do próprio judaísmo podiam assumir verbalmente uma generalização que dificilmente conseguiria ser entendida literalmente.

Examinando logicamente os textos dos Evangelhos, devemos dizer que nem a maioria do povo de Israel daquela época, nem sequer a maioria dos habitantes de Jerusalém tomaram parte ativa nos acontecimentos que levaram à morte de Jesus. Mesmo entre os "escribas e fariseus", parece ter existido uma pluralidade de opiniões maior do que à primeira vista possa parecer. A acusação indiscriminada de "deicídio" contra todos os judeus contemporâneos de Jesus e muito menos contra os posteriores a essa época não se pode fundamentar nos relatos evangélicos.

Em Paulo, o problema do juízo sobre o povo de Israel parece ser mais complexo. O zelo pelo judaísmo, que impulsionou o Apóstolo a tomar parte na repressão inicial contra o cristianismo nascente, acabou transformando-se em ardor proselitista pela nova religião, ao mesmo tempo em que sentia den-

\footnotetext{
3 "Não se pode ignorar a diferença que existe entre o anti-semitismo, baseado em teorias contrárias ao constante ensinamento da Igreja acerca da unidade do gênero humano e a igual dignidade de todas as raças e de todos os povos, e os sentimentos de suspeita e de hostilidade que perduram há séculos, a que chamamos antijudaísmo, dos quais, infelizmente, também cristãos foram culpados".
} 
tro de si o desgarramento interior, por causa de sua pertença pessoal ao povo hebreu. Nenhum outro escrito do Apóstolo exprime isso melhor do que a Carta aos Romanos, inquestionavelmente paulina. Junto com a Carta aos Gálatas, Romanos focaliza o problema principal da teologia paulina: a justificação pela fé. Mas, enquanto a Carta aos Gálatas foi escrita no ardor da polêmica intracristã, a Epístola aos Romanos é fruto de uma reflexão amadurecida sobre o mistério da salvação e o seu desenrolar na História. Eis um breve resumo dela:

O contexto é o de uma comunidade (a de Roma), onde, de acordo com as informações recebidas por Paulo, as divergências parecem conduzir a sérios desentendimentos entre os cristãos convertidos do judaísmo, de um lado, e os convertidos do paganismo, do outro. O escrito prepara uma visita do Apóstolo a essa comunidade, propondo uma solução para os problemas lá existentes, especificamente o da relação judaísmo-cristianismo. Na epístola, Paulo parte da contraposição entre Cristo, Justiça de Deus, e a justiça que os homens pretendem alcançar por seu próprio esforço, mediante as obras. Não nega o valor da antiga economia da salvação, mas lhe marca limites precisos. "A Lei é santa, justo e bom é o preceito" (Rm 7,12), anuncia claramente Paulo de Tarso; a Lei fez o homem conhecer a vontade divina. Ao mesmo tempo, ele se enfrenta com o problema da própria debilidade e a consciência da própria culpa e não consegue ver na Lei a ajuda necessária para superálas. Daí a sua solução: somente em Cristo, encontra-se essa ajuda e ela se obtém através da fé. A conseqüência lógica dessas premissas seria a exclusão da salvação de todos os judeus que permanecessem no judaísmo.

Não é, pois, estranho que os escritos paulinos tenham sido considerados fonte da polêmica judeu-cristã e até acusados de serem anti-semitas. Contudo, Paulo, na mesma Carta aos Romanos, não parece satisfeito com aquela dedução e passa a polemizar com os cristãos provenientes da gentilidade que, numa soberba mal dissimulada, desprezavam os judeus. Contra as conotações racistas que pareciam insinuar-se, ele deixa muito claro que, diante de Deus, não há acepção de pessoas. Todos os fiéis, seja qual for a sua origem - israelita ou gentílica -, devem formar um só corpo (cf. Rm 12,115). Além disso - e este é o ponto mais importante -, Paulo está convencido de que aos israelitas "pertencem a adoção filial, a glória, as alianças, a legislação, o culto, as promessas, os patriarcas"; deles é "o Cristo segundo a carne" (Rm 9,4-5). Nos capítulos 10 e 11, a argumentação torna-se um tanto confusa, pois confusa parece estar à mente de Paulo, perante o mistério da salvação e os insondáveis desígnios de Deus. Por um lado, ele vê o que julga ser a incredulidade de Israel e the parece que, ao agirem os judeus desse modo, fica fechada para eles a porta da salvação. Por outro, porém, tem que 
reconhecer que "os dons e a vocação [eleição] de Deus são sem arrependimento [irrevogáveis]" (Rm 11,29). Daí conclui afirmando que "Deus encerrou todos na desobediência para a todos fazer misericórdia" (Rm 11, 32). A partir daí, entoa um hino à sabedoria misericordiosa do Senhor, aceitando aquilo que sua mente não pode compreender por inteiro.

Paulo, dentro de um contexto de sentimentos contrapostos, focaliza a dialética entre salvação individual e salvação comunitária do povo, mas não consegue chegar a uma conclusão completamente satisfatória para o seu raciocínio. A solução final a essa questão é uma solução que apela para a fé e para o mistério e, ao mesmo tempo, apresenta uma certeza que ele exprime deste modo: "Não quero que ignoreis, irmãos, este mistério, para que não vos tenhais na conta de sábios: o endurecimento atingiu uma parte de Israel, até que chegue a plenitude dos gentios, e assim todo Israel será salvo, conforme está escrito:

\section{De Sião virá o libertador e afastará as impiedades de Jacó, e esta será minha aliança com eles, quando eu tirar seus pecados".}

Diante dessas afirmações, é lícito perguntar-nos se, para Paulo, dada a irrevogabilidade da promessa divina, o judaísmo continua a ser caminho de salvação - imperfeito, sim, mas verdadeiro - para o povo de Israel, à espera de que "todo Israel" seja salvo. E, se Paulo pensava assim, podemos nós pensar de modo diferente? Até que ponto, então, é legítimo o proselitismo cristão entre os judeus?

Pe. Jesus Hortal, S.J. Reitor da PUC-Rio 